\title{
The Effect of Omega-3 Therapy on Induced Hyperacidity
}

\author{
Authors

\section{Hader Ibrahim Sakr ${ }^{1}$, Mohamed Mansour Khalifa ${ }^{1}$, Mohamed Al Sayed Saleh ${ }^{1}$,} \\ Laila Ahmed Rashed $^{2}$, Akef Abdelhalim Khowailed ${ }^{1}$ \\ ${ }^{1}$ Department of Medical Physiology, Kasr Al Ainy Faculty of Medicine, Cairo University, Cairo, Egypt \\ ${ }^{2}$ Department of Biochemistry, Kasr Al Aini Faculty of Medicine, Cairo University, Cairo, Egypt \\ Corresponding Author \\ Hader Ibrahim Sakr, MD \\ Department of Medical Physiology, Kasr Al Ainy Faculty of Medicine, Cairo University, Cairo Egypt \\ Email: hadersakr209@yahoo.com, hadersakr@kasralainy.edu.eg
}

Mobile phone: +201111616364

\begin{abstract}
Gastric hyperacidity is a serious health problem of global concern. This work was conducted to study the effect of chronic administration of omega-3 polyunsaturated fatty acids (PUFA) on $\mathrm{HCl}$ secretion and stress-induced ulcer in male albino rats. Study groups included 24 rats divided into 2 main groups with 12 rats in each as follows: pyloric ligation group $(A)$ and water immersion-induced gastric ulceration group (B). Each subgroup contained 6 rats. Among the parameters estimated in the studied groups were: free and total HCL secretion in group A, and ulcer score, ulcer index, percentage ulcer protection, histology of the stomach, eNOS enzyme activity, COX-2 enzyme activity, glutathione reductase enzyme gene expression, $C C K$ gene expression and proton pump $\left(H^{+} / K^{+}\right.$ATPase $)$gene expression in group $B$.

RESULTS showed significant decrease in free and total acidity, ulcer score and index, COX-2 enzyme activity and Proton pump $\left(\mathrm{H}^{+} / \mathrm{K}^{+}\right.$ATPase $)$gene expression among $\omega$-3 fed rats compared with the results of the control group. On the other hand significant elevation was observed in the percentage ulcer protection, eNOS enzyme activity, glutathione reductase gene expression and CCK gene expression among omega-3 fed rats compared to control group.

CONCLUSION, the present study revealed a protective effect of omega-3 PUFA on stress-induced gastric ulceration.
\end{abstract}

Key words: Gastric hyperacidity, $\mathrm{HCl}, \mathrm{H}^{+} / \mathrm{K}^{+}$ATPase pump, $\mathrm{H}_{2}$-receptor blockers, omega-3 PUFA.

\section{INTRODUCTION}

Dietary fat includes all the lipids in plant and animal tissues that are eaten as food. The most common fats (solid) or oils (liquid) are glycerollipids, which are essentially composed of triglycerides (TGs). Fatty acids constitute the main components of these lipid entities and are required in human nutrition as a source of energy and for metabolic and structural activities ${ }^{1}$. Omega-6 and omega-3 PUFA are important structural components of the phospholipids cell membranes of the tissues, which have multiple physiological functions ${ }^{2,3}$. The composition of the phospholipids influences cell membrane characteristics such as fluidity and permeability to other molecules. They are essential for various 
membrane functions such as activity of membrane-bound enzymes and receptors and signal transduction ${ }^{4}$.

Stress-induced lesions in the gastrointestinal tract can cause overt bleeding and hemodynamic instability in critically ill patients ${ }^{5}$. The mechanism of stress ulcer is believed to be multifactorial and is not completely understood. It involves a complex set of interactions that causes a breakdown of the mucosal protective defenses allowing aggressive physiological factors to produce injury and ulceration ${ }^{6}$. Many factors such as gastric acid and pepsin secretion, gastric microcirculation, prostaglandin $\mathrm{E}_{2} \quad\left(\mathrm{PGE}_{2}\right)$ content $^{7}$, splanchnic hypo-perfusion ${ }^{5}$ and proinflammatory cytokines. Among these cytokines are interleukin 1 (IL-1) and tumor necrosis factor alpha (TNF- $\alpha)^{8}$ which play - each in different way - important roles in the genesis of gastric mucosal damage and its subsequent development. The mechanism of water-immersion and restraint stress-induced gastric mucosal lesion is complicated and not yet fully understood. The pathogenesis of the injury may be recognized at different levels, for example, at psychological, physiological, psychosomatic $^{9}$, integrative, organic, cellular and molecular levels. Shu et al. (2012) differentiated the relative importance of the pathways by which the stress stimulus signals were sensed and transferred to the central nervous system $(\mathrm{CNS})^{10}$. Thus, the aim of the work was to investigate, the possible effect of chronic administration of omega-3 polyunsaturated fatty acids on gastric acid secretion and to study if this action has any effect on stress-induced ulcers in male albino rats.

\section{MATERIALS \& METHODS}

EXPERIMENTAL ANIMALS: A total of 24 male albino rats weighing 150-175 gm were used. The rats were housed in wire mesh cages at room temperature, veterinary care was provided by laboratory animal house unit of Kasr Al-Ainy faculty of medicine, Cairo University. Before the day of experiments all rats were starved for 24 hours, with free access to water until the beginning of experimental protocol.

CHEMICALS: Omega-3 fatty acids: omax3. Prevention pharmaceuticals. 24 Arnett Avenue, Suite 107, Lambertville, NJ 08530.

EXPERIMENTAL PROTOCOL: Rats were divided into two groups:

Group A: experimental design for pyloric ligation induced gastric ulcer: 12 rats were divided into 2 subgroups, each consists of 6 animals:

Subgroup i: fed for 6 weeks on a standard laboratory rat diet offered $a d$ lib.

Subgroup ii: fed for 6 weeks on a standard laboratory rat diet enriched with $100 \mathrm{~g} / \mathrm{kg}$ of $\omega-3$ PUFA $^{11}$ offered ad lib.

On the 35th day, the 3 groups of rats were fasted 24 hours prior to induction of gastric ulcer. Pyloric ligation was done by ligating the pyloric end of the stomach of rats ${ }^{12}$. Animals were allowed to recover and stabilized in individual cage and were deprived of water during postoperative period. After 3 hours of surgery, rats were sacrificed by cervical dislocation.

Both free and total $\mathrm{HCl}$ secretion were measured in this group (A).

Group B: experimental design for waterimmersion restraint-induced gastric ulcer: 12 rats will be divided into 2 subgroups, each consists of 6 animals:

Subgroup i: fed for 6 weeks on a standard laboratory rat diet offered ad lib.

Subgroup ii: fed for 6 weeks on a standard laboratory rat diet enriched with $100 \mathrm{~g} / \mathrm{kg}$ of $\omega-3$ PUFA offered $a d l i b$.

The rats were fasted 24 hours prior to stress induction. Rats were immobilized in a stress cage and then immersed to the level of the xiphoid in a water bath at $23 \pm 0.2^{\circ} \mathrm{C}$ for 4 hours ${ }^{13}$. Then they were removed from the cage and sacrificed by cervical dislocation. Ulcer score, ulcer index, percentage ulcer protection, histology of the Stomach, eNOS enzyme gene expression, COX-2 enzyme activity, glutathione reductase enzyme gene expression, CCK gene expression and 
proton-pump $\left(\mathrm{H}^{+} / \mathrm{K}^{+}\right.$ATPase enzyme $)$gene expression were measured in this group (B).

\section{DETERMINATION OF ULCER INDEX:}

Stomachs of group B (water immersion rats) were opened at the greater curvature, fixed on cork for determination of ulcer index. The Ulcer index was calculated according to the method of Suzuki et al., $1976^{\mathbf{1 4}}$. The lesions were counted with the aid of hand lens (10X) and each given a severity rating as follows:

a) 1 Less than $1 \mathrm{~mm}$ (Pin point)

b) 21-2 $\mathrm{mm}$

c) 3 Greater than $2 \mathrm{~mm}$ and above

The ulcer score was divided by a factor of 10 to get the ulcer index.

\section{DETERMINATION OF PERCENTAGE} ULCER PROTECTION: Percentage ulcer protection was calculated by the formula ${ }^{15}$ :

Ulcer protection $(\%)=\left(\mathrm{U}_{\mathrm{c}}-\mathrm{U}_{\mathrm{t}} / \mathrm{U}_{\mathrm{c}}\right) \times 100$

Where:

$\mathrm{U}_{\mathrm{c}}=$ ulcer index of control group.

$\mathrm{U}_{\mathrm{t}}=$ ulcer index of test group.

PYLORIC LIGATION: An aseptic surgical procedure was employed for group (A) animals. The rats were anesthetized by intra-peritoneal injection with thiopental sodium $(30 \mathrm{mg} / \mathrm{kg})$, after that the abdomen was opened by a small midline incision of approximately $3 \mathrm{~cm}$, at one $\mathrm{cm}$ below the xiphoid process. Stomach was exposed and a tight knot was applied around the pyloric sphincter using 4-0 silk ligature. The stomach was placed carefully and abdomen wall closed by interrupted sutures. Immediately after suturing the incision, the wound was cleaned and covered by local antibiotic ointment (Terramycin). The rats were returned to their cages and left for 3 hours ${ }^{12}$.
ANIMAL SACRIFICE AND SAMPLES COLLECTION: Animals were sacrificed by cervical dislocation, the thorax and abdomen were opened, esophagus was ligated and the stomachs were dissected and removed quickly. The contents of the stomach were collected.

MEASUREMENT OF GASTRIC ACID SECRETION: After collection of gastric fluid, the total volume of gastric content was measured. The gastric contents were centrifuged at $1000 \mathrm{rpm}$ for $10 \mathrm{~min}$. One $\mathrm{ml}$ of the supernatant liquid was pipetted out and diluted to $10 \mathrm{ml}$ with distilled water. The solution was titrated against $0.01 \mathrm{~N}$ $\mathrm{NaOH}$ using Topfer's reagent as indicator, to the endpoint when the solution turned to orange color. The volume of $\mathrm{NaOH}$ needed was taken as corresponding to the free acidity. Titration was further continued till the solution regained pink color. The volume of $\mathrm{NaOH}$ required was noted and taken as corresponding to the total acidity ${ }^{16}$.

\section{MEASUREMENT OF COX-2 ENZYME} ACTIVITY: By using Cayman's COX activity assay kit. Cayman's COX Activity Assay Kit measures the peroxidase activity of COX. The peroxidase activity is assayed colorimetrically by monitoring the appearance of oxidized N,N,N,N'tetramethyl- $p$-phenylenediamine (TMPD) at 590 $\mathrm{nm}^{17}$. It can be used with both crude (cell lysates/tissue homogenates) and purified enzyme preparations. The kit includes isozyme-specific inhibitors for distinguishing COX-2 activity from COX-1 activity.

DETECTION OF eNOS, CCK, GLUTATHIONE REDUCTASE AND H+/K+ ATPase GENE EXPRESSION BY REAL TIME-PCR: Quantitative Real Time PCR Protocol. Real time quantitative polymerase chain reaction (qPCR) differs from regular PCR by including in the reaction fluorescent reporter molecules that increase proportionally with the increase of DNA amplification in thermocycler. There are two types of fluorescent chemistries for this purpose: double-strand DNA-binding dyes and fluorescently labeled sequence specific probe/primer. SYBR Green I dye and TaqMan ${ }^{\circledR}$ hydrolysis probe are the common examples for these two, respectively. The SYBR Green method doesn't need fluorescently labeled probe/primer and costs much less than the TaqMan ${ }^{\circledR}$ method. The key equipment for qPCR is a specialized 
thermocycler with fluorescence detection modules which is used to monitor and record the fluorescence in real time as amplification occurs. A typical workflow of qPCR for gene expression measurement involves RNA isolation, reverse transcription, qPCR assay development, qPCR experiment and data analysis.

\section{RESULTS}

The results of present work showed a highly significant $(\mathrm{P}$-value $<0.05)$ decrease in the mean values of both total and free acidity between subgroup Aii ( $\omega-3$ fatty acids fed) and control subgroup Ai. As shown in Table 1 and Figure (1), the mean value of total acidity of subgroup Ai was $71.683 \mathrm{mEq} / \mathrm{L} \pm 1.076$ and that of free acidity was $29.733 \mathrm{mEq} / \mathrm{L} \pm 0.628$, while in subgroup Aii, the mean value of total acidity was $61.267 \mathrm{mEq} / \mathrm{L} \pm$ 0.683 and that of free acidity was $19.517 \mathrm{mEq} / \mathrm{L} \pm$ 0.771. The results of the present work also showed a highly significant (P-value $<0.05$ ) decrease in ulcer index between $\omega-3$ fatty acids fed rats (subgroups Bii) with a mean value of 0.5 \pm 0.089 and control subgroup $\mathrm{Bi}$ in which the mean value of the ulcer indices was $1.117 \pm 0.075$ (Table 2 and Figure (2)). The mean value of percentage ulcer protection among $\omega-3$ fatty acids fed rats (subgroup Bii) was 54.293\% \pm 8.724 .

Table (1): Comparison of total acidity, free acidity and ulcer index between subgroups Ai (control) and Aii $(\omega-3$ fatty acids fed $)$

\begin{tabular}{|l|c|c|c|}
\hline \multicolumn{2}{|c|}{} & Subgroup Ai & Subgroup Aii \\
\hline \multirow{2}{*}{$\begin{array}{l}\text { Total } \\
\text { acidity }\end{array}$} & Mean $^{\#}$ & 71.683 & 61.267 \\
\cline { 2 - 4 } Free & S.D. \pm & 1.076 & 0.683 \\
acidity & Mean $^{\#}$ & 29.733 & 19.517 \\
\cline { 2 - 4 } & S.D. \pm & 0.628 & 0.771 \\
\hline
\end{tabular}

\#Mean is in $\mathrm{mEq} / \mathrm{L}$

*:statistically significant compared to corresponding value in subgroup $\mathrm{Bi}(\mathrm{P}<0.05)$.

Table (2): Comparison of total acidity, free acidity and ulcer index between subgroups Bi (control) and Bii $(\omega-3$ fatty acids fed $)$

\begin{tabular}{|c|c|c|c|}
\hline & Subgroup Bi & Subgroup Bii \\
\hline \multirow{2}{*}{$\begin{array}{l}\text { Ulcer } \\
\text { index }\end{array}$} & Mean & 1.117 & 0.5 \\
\hline & S.D. \pm & 0.075 & 0.089 \\
\hline & & & $<0.05^{*}$ \\
\hline
\end{tabular}

${ }^{\#}$ Mean is in $\mathrm{mEq} / \mathrm{L}$

*: statistically significant compared to corresponding value in subgroup $\mathrm{Bi}(\mathrm{P}<0.05)$. 


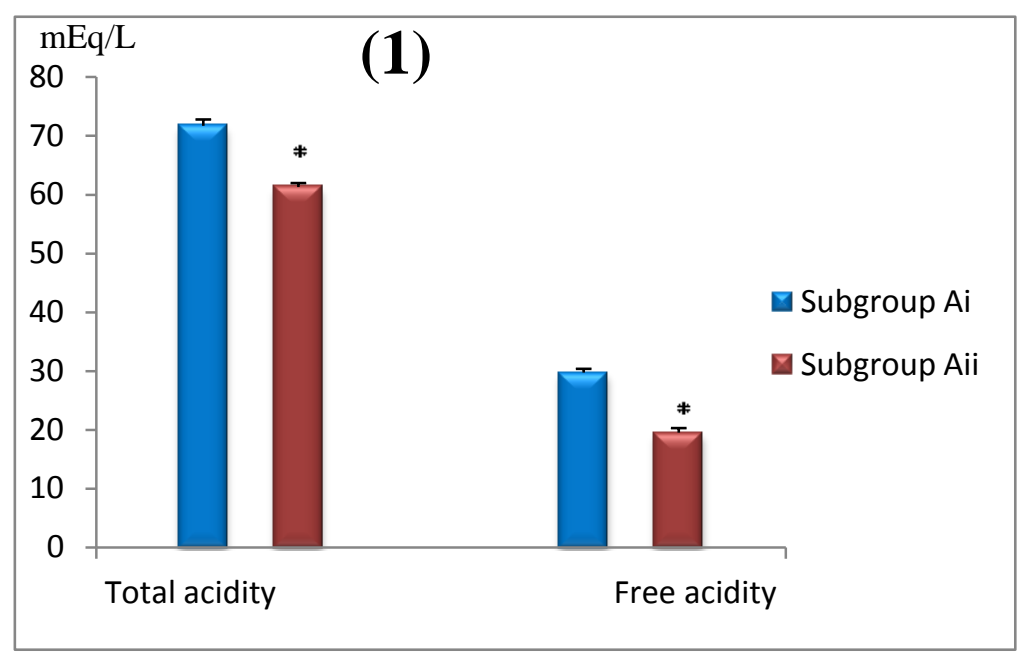

Values are represented as mean \pm SD.

*: statistically significant compared to corresponding value in subgroups $\mathrm{Ai}(\mathrm{P}<0.05)$.

Figure (1): Comparison of total and free acidity between subgroup Ai (control) and Aii ( $\omega-3$ fatty acids fed).

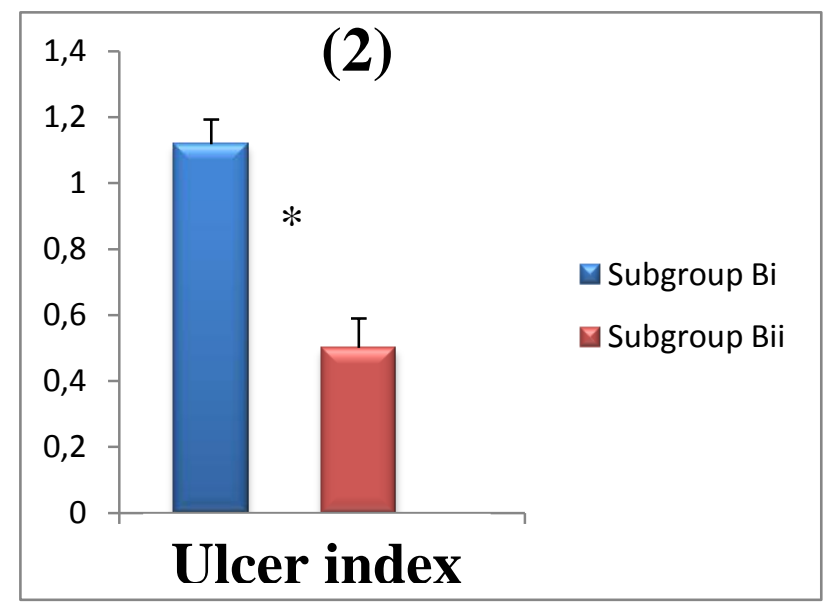

Values are represented as mean $\pm \mathrm{SD}$.

*: statistically significant compared to corresponding value in subgroups $\mathrm{Bi}(\mathrm{P}<0.05)$.

Figure (2): Comparison of ulcer indices between subgroup Bi (control) and Bii ( $\omega$-3 fatty acids fed).

(3)

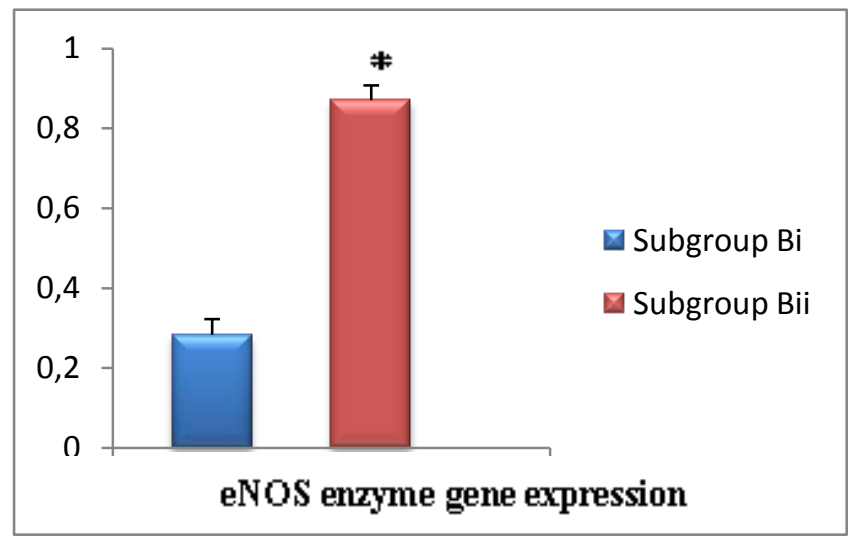

(4)

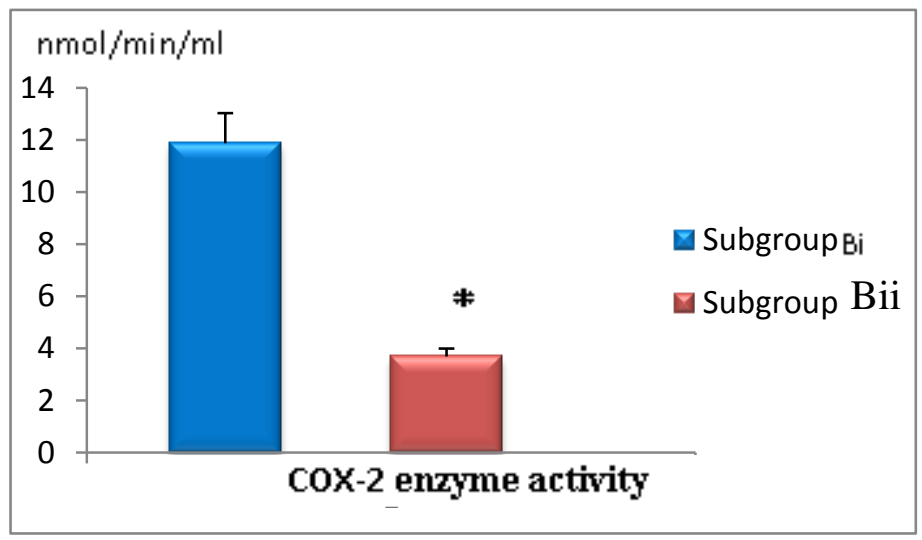


(5)

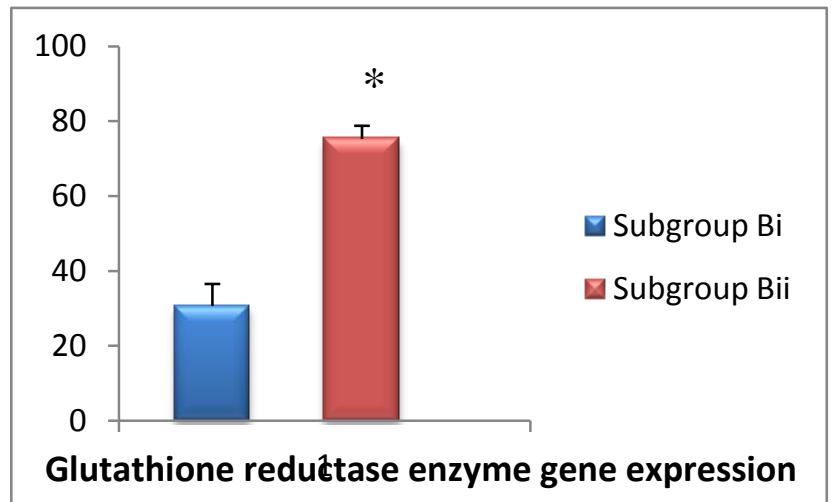

(7)
(6)

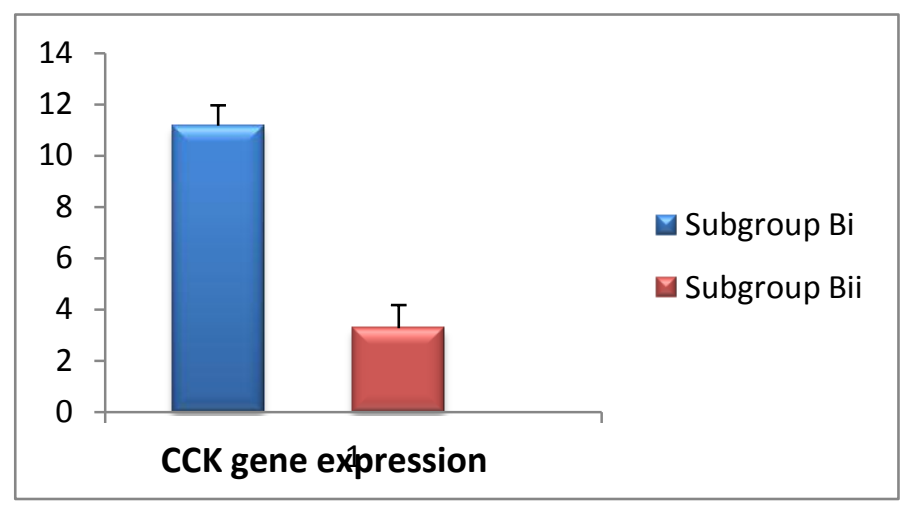

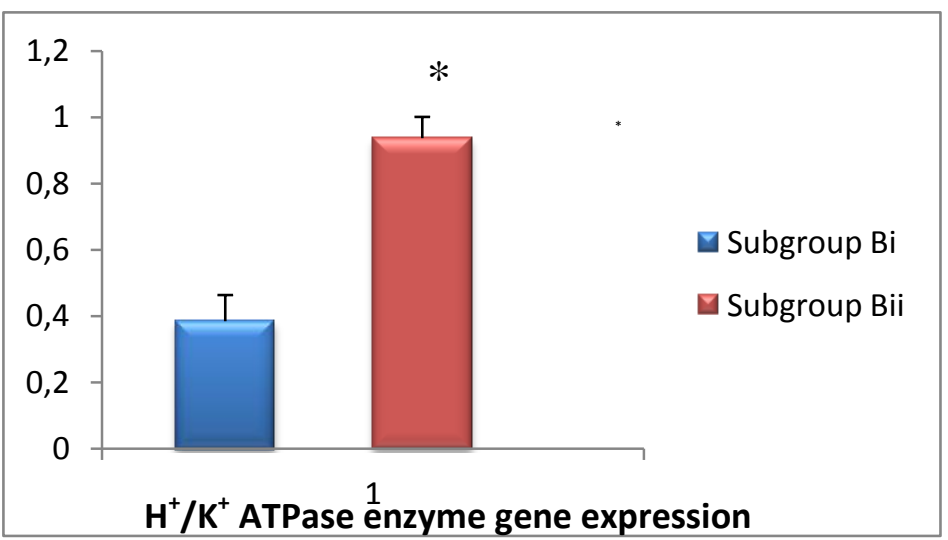

Values are represented as mean \pm SD.

* Statistically significant compared to corresponding value in subgroup $\mathrm{Bi}(\mathrm{P}<0.05)$

Figure (3): Comparison of eNOS enzyme gene expression between subgroups Bi (control) and Bii $(\omega-3$ fatty acids fed).

Figure (4): Comparison of COX-2 enzyme activity between subgroups Bi and Bii.

Figure (5): Comparison of glutathione reductase enzyme gene expression between subgroups Bi and Bii. Figure (6): Comparison of $\mathrm{H}^{+} / \mathrm{K}^{+}$ATPase enzyme gene expression between subgroups $\mathrm{Bi}$ and $\mathrm{Bii}$.

Figure (7): Comparison of CCK gene expression between subgroups $\mathrm{Bi}$ and $\mathrm{Bii}$

The results of present work - as seen in Table 3 also showed a highly significant $(\mathrm{P}$-value $<0.05)$ increase in eNOS enzyme gene expression between subgroup Bii ( $\omega-3$ fatty acids fed) with a mean value of $0.87 \pm 0.037$ and control subgroup Bi with a mean value of $0.283 \pm 0.039$ (Figure 3). Furthermore, the results also showed a highly significant (P-value < 0.05) decrease in COX-2 enzyme activity between subgroup Bii with a mean value of $4.118 \mathrm{nmol} / \mathrm{min} / \mathrm{ml} \pm 0.305$ and subgroup $\mathrm{Bi}$ with a mean value of 11.647 $\mathrm{nmol} / \mathrm{min} / \mathrm{ml} \pm 1.156$ (Figure 4 ). In addition, the results have shown a highly significant (P-value < $0.05)$ increase in glutathione reductase enzyme gene expression between subgroup Bii with a mean value of $75.283 \pm 3.527$ and subgroup $\mathrm{Bi}$ with a mean value of $30.733 \pm 5.854$ (Figure 5). The results also showed a highly significant (Pvalue $<0.05$ ) decrease in $\mathrm{H}^{+} / \mathrm{K}^{+}$ATPase enzyme gene expression between subgroup $\mathrm{Bii}$ with a mean value of $3.268 \pm 0.902$ and subgroup $\mathrm{Bi}$ with a mean value of $11.167 \pm 0.794$ (Figure 6). In addition, the results showed a highly significant (P-value < 0.05) increase in CCK gene expression between subgroup Bii with a mean value of 0.937 \pm 0.064 and subgroup $\mathrm{Bi}$ with a mean value of $0.385 \pm 0.079$ (Figure 7). In addition, the current results - from macroscopic and microscopic (histo-pathological) examination - recorded more significant protection against stress-induced 
gastric ulcer in $\omega-3$ fatty acids fed rats (subgroup Bii) Figures (9) and (11) as compared to control subgroup Bi Figures (8) and (10).

Table (3): Comparison of eNOS enzyme gene expression, COX-2 enzyme activity, glutathione reductase enzyme gene expression, $\mathrm{H}^{+} / \mathrm{K}^{+}$ATPase enzyme gene expression and CCK gene expression between subgroups Bi (control) and Bii ( $\omega-3$ fatty acids fed).

\begin{tabular}{|l|l|l|l|}
\hline \multicolumn{2}{|c|}{} & Subgroup Bi & Subgroup Bii \\
\hline \multirow{2}{*}{$\begin{array}{l}\text { eNOS enzyme gene } \\
\text { expression }\end{array}$} & Mean & 0.283 & 0.87 \\
\cline { 2 - 4 } & S.D. \pm & 0.039 & 0.037 \\
\hline \multirow{2}{*}{$\begin{array}{l}\text { COX-2enzyme activity } \\
\text { glutathione reductase } \\
\text { enzyme gene expression }\end{array}$} & Mean & 11.647 & 4.118 \\
\cline { 2 - 4 } & S.D. \pm & 1.156 & 0.305 \\
\hline \multirow{2}{*}{$\begin{array}{l}\mathrm{H}^{+} / \mathrm{K}^{+} \text {ATPase enzyme } \\
\text { gene expression }\end{array}$} & S.D. \pm & 30.733 & 75.283 \\
\hline \multirow{2}{*}{$\begin{array}{l}\text { CCK gene expression } \\
\text { P Value }\end{array}$} & S.D. \pm & 5.854 & 3.527 \\
\cline { 2 - 4 } & Mean & 11.167 & 3.268 \\
\cline { 2 - 4 } & S.D. \pm & 0.794 & 0.902 \\
\hline \multicolumn{2}{|l}{$\#$} & 0.079 & 0.937 \\
\hline
\end{tabular}

\# Mean is in $\mathrm{nmol} / \mathrm{min} / \mathrm{ml}$

*: statistically significant compared to corresponding value in subgroup $\mathrm{Bi}(\mathrm{P}<0.05)$

(8)

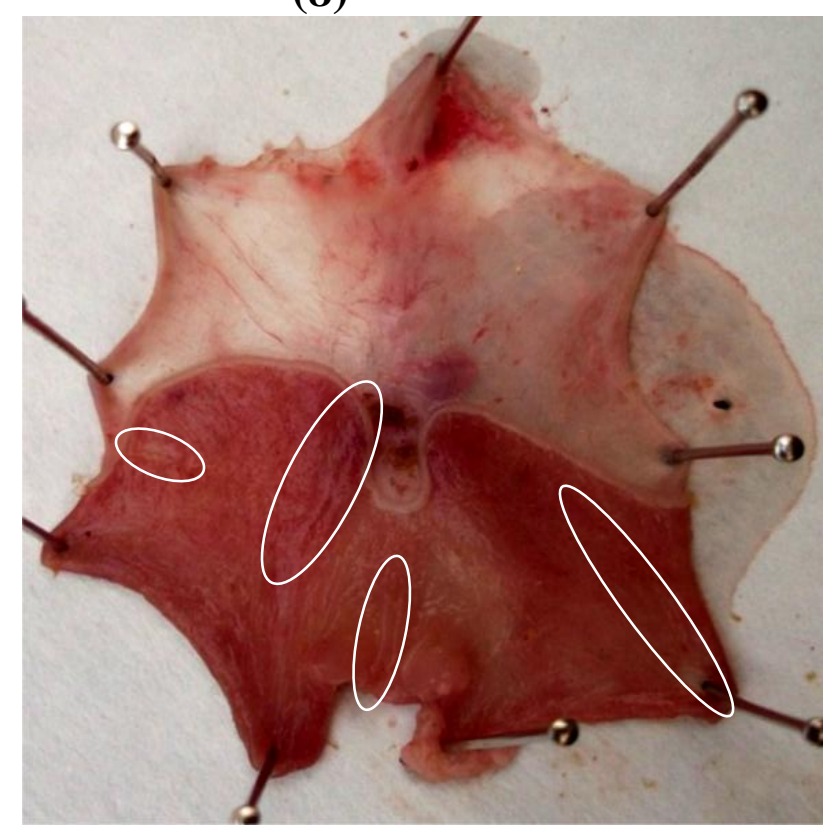

(9)

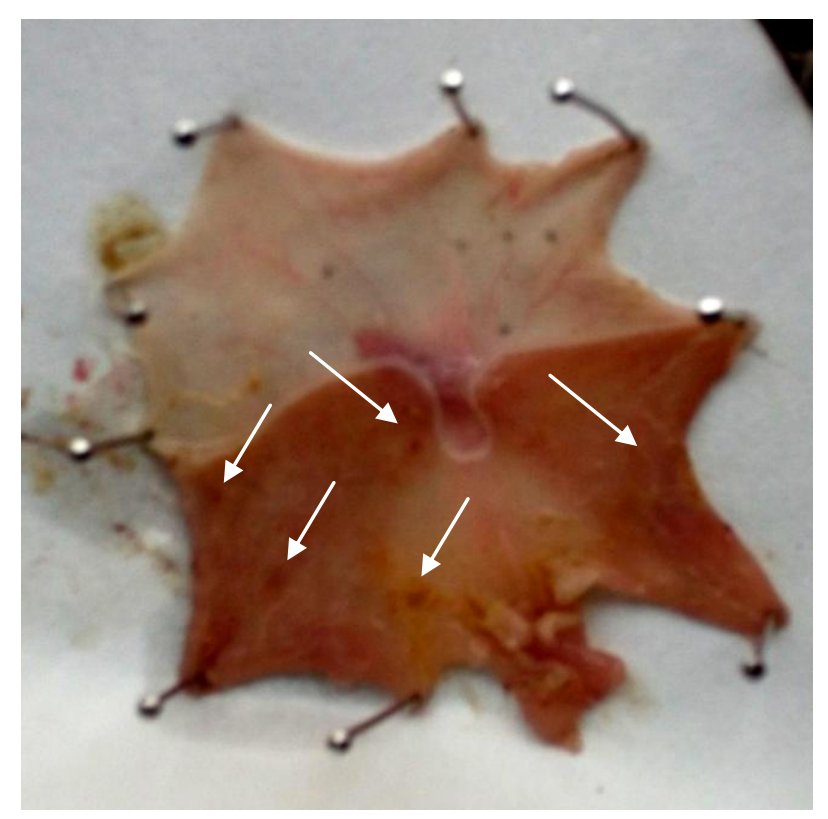

Figure (8): Macroscopic representation of gastric mucosa of Subgroup Bi (control group).

Figure (9): Macroscopic representation of gastric mucosa of group I Subgroup Bii (Omega-3 fed group). 

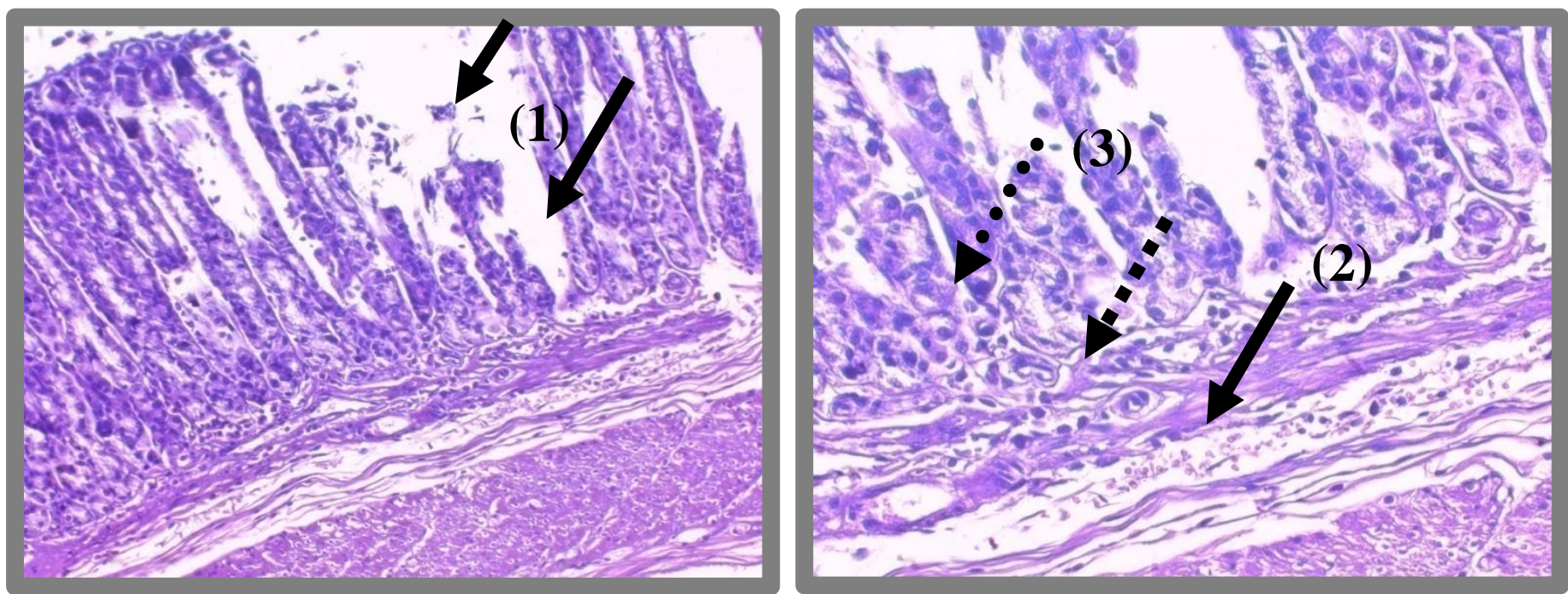

Sections of gastric excision biopsies revealing wide ulceration of the gastric mucosa (1), with edematous lamina propria (2) with severe lymphoplasma cell infiltrate with excess neutrophils (3 dashed arrows). (A picture is consistent with severe acute ulcerative gastritis.)

Figure (10): Microscopic representation (10X and 20X) of gastric mucosa of subgroup Bi (control group) stained with Hx \& E.
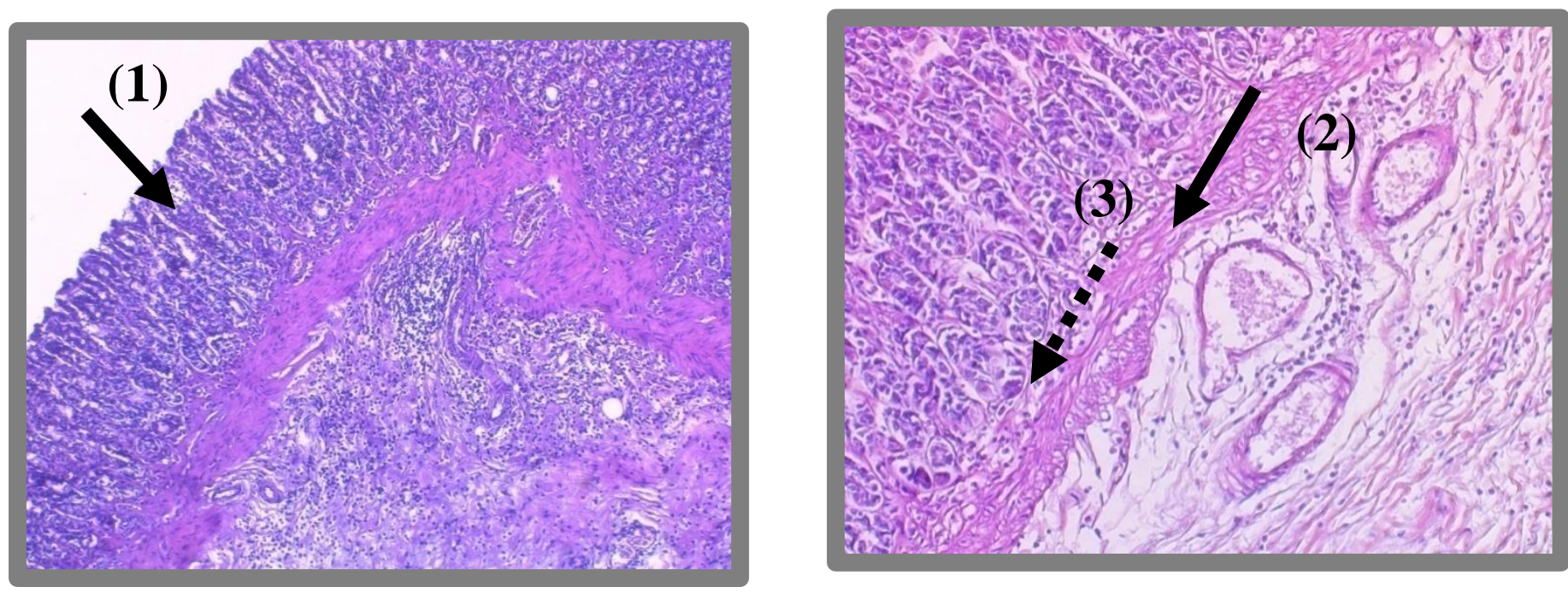

Sections of gastric excision biopsies revealing intact gastric mucosa (1), and moderately edematous lamina propria with engorged capillaries (2) and mild lymphoplasma cell infiltrate with neutrophils (3 dashed arrows).

(A picture consistent with mild acute gastritis)

Figure (11): Microscopic representation (10X and 20X) of gastric mucosa of Subgroup Bii (omega-3 fed group) stained with $\mathrm{Hx} \& \mathrm{E}$.

\section{DISCUSSION}

The results of the present work illustrated that feeding rats with $\omega-3$ fatty acids (subgroups Bii) produced significant reduction in stress-induced gastric ulcer. The results of the present work demonstrated that stress-induced gastric ulcer produced by water immersion for 4 hours at temperature of $23 \pm 0.2{ }^{\circ} \mathrm{C}$ in control group (as a form of acute stress) was significantly reduced after adding $100 \mathrm{~g} / \mathrm{kg}$ fish oil for the experiment period of 6 weeks. These results are consistent with the work of Shu et al., (2012) ${ }^{10}$. On the other 
hand Faust et al. $1990^{18}$ denied the presence of any cyto-protective effect of $\omega$-3 fatty acids on gastric ulcer. He stated that fish oil feeding had no significant effect on mucosal prostaglandin $E_{2}$ or $\mathrm{F}_{2}$ alpha content or on the damaging effect of aspirin on the stomach.

The effect of $\omega-3$ fatty acid on the development of gastric ulcer has been studied extensively. Fish oil, rich in $\omega-3$ fatty acid, is reported to reduce gastric acid secretion ${ }^{19}$. Although earlier reports on the effect of cod liver oil (CLO) on gastric ulcers are confusing, studies carried out using different constituents of fish oils such as $\omega-3$ polyunsaturated fatty acids reveal that they possess antiulcer and antioxidant effect ${ }^{20}$. $\Omega-3$ triglycerides are also known to inhibit ulcer formation in pylorus ligated rats ${ }^{21}$ and increase healing of gastric ulcers in rats ${ }^{22}$.

On measuring total and free acidity, the results of present work demonstrated that $\omega$-3 fatty acids fed rats (subgroup Aii) had a highly significant decrease in their mean values compared to control subgroup Ai. $\Omega-3$ fatty acids fed rats had also a highly significant increase in the mean value of CCK gene expression compared to control subgroup Ai.

It is well known that intra-duodenal administration of fat inhibits gastric acid secretion and stimulates the release of several gut peptides including secretin and cholecystokinin (CCK) in the $\mathrm{rat}^{23}$, in the $\operatorname{dog}^{24}$, and in the human ${ }^{25}$. Some studies ${ }^{26}$ show that in humans endogenous CCK exerts a similar inhibitory influence on gastric acid secretion and gastrin release. The exact role of CCK as a mediator of the inhibition of gastric acid secretion and gastrin release remains unclear, although two mechanisms could account for these effects. First, a negative feed-back mechanism controlling gastrin secretion and mediated by CCK could exist. In vitro experiments have shown that CCK can potently stimulate somatostatin release from isolated canine fundic mucosal cells $^{27}$. It is also well documented that gastrin secretion is under somatostatin control in rats ${ }^{28}$. A second mechanism would imply other inhibitory peptides which plasma levels increase after the ingestion of a fatty meal, with their release being mediated, at least in part, by CCK. One possible candidate could be pancreatic polypeptide (PP) ${ }^{29}$. The results of present work demonstrated that $\omega-3$ fatty acids fed rats (subgroups Bii) had a highly significant decrease in the mean value of gastric $\mathrm{H}^{+} / \mathrm{K}^{+}$ATPase enzyme activity and the mean value of ulcer index compared to the control group (subgroups Bi). Hyperacidity is a pathological condition due to uncontrolled hypersecretion of hydrochloric acid from the parietal cells (PC) of gastric mucosa through the proton pumping by $\mathrm{H}^{+} / \mathrm{K}^{+}$ATPase harbored on the plasma membrane of $\mathrm{PC}^{30}$.

Fish oil, rich in $\omega-3$ fatty acid, is reported to inhibit offensive mucosal factors and oxidative stress and to augment defensive mucosal factors ${ }^{31}$. Further, fish oil reduced development of cold plus restraint ulcers in rats ${ }^{32} . \Omega-3$ fatty acid had proved its cyto-protective action in gastric mucosa of rats against stress induced damage by its antioxidant mechanism $^{33}$.

It has been suggested that the use of $\omega-3$ PUFAs may have ameliorating effect on ROS damage to gastric mucosa by two possible ways: First, $\omega-3$ PUFA may increase the levels of catalase enzyme within the peroxisome and in the cytoplasm resulting in enhanced defense against free oxygen radicals. Second, $\omega-3$ PUFAs that has been supplemented may replace polyunsaturated fatty acid components of the membranes that had been attacked by oxygen free radicals such as superoxide anions, hydrogen peroxide and hydroxyl radicals ${ }^{34}$.

In addition to its ameliorating effect on ROS, tissues metabolize PUFAs to oxygenated products that have much more potent impacts on peroxisome proliferator-activated receptor gamma (PPAR- $\gamma$ ) than their parent molecules ${ }^{35}$. The antiinflammatory LTs, $\mathrm{PGD}_{2}, \mathrm{PGE}_{1}, \quad \mathrm{PGIs}$, are derived from n-3 PUFAs eicosapentaenoic acid (EPA) and docosahexaenoic acid (DHA) ${ }^{36}$. The beneficial effect of fish consumption with high contents of EPA and DHA might be attributed to 
the displacement of AA from the cell membrane phospholipid and to a preferential formation of less pro-inflammatory PGs (such as $\mathrm{PGE}_{3}, \mathrm{PGF}_{3 \alpha}$, $\mathrm{TXA}_{3}$ ), and LTs (such as $\mathrm{LTB}_{5}, \mathrm{LTC}_{5}$, and $\left.\mathrm{LTD}_{5}\right)^{37}$.

The PPAR family of nuclear receptors comprises three distinct gene products, PPAR- $\alpha, \beta / \delta$ and $\gamma$, that differ in ligand specificity, tissue distribution, and developmental expression ${ }^{38}$. Reports showed gastric expression of PPAR $-\gamma^{39}$. The activation of PPAR- $\gamma$ significantly accelerates the ulcer healing by the mechanism involving $\mathrm{NO}^{40}$. Several previous studies indicated a central role of NO in protection of gastric mucosa, mainly due to an improvement of gastric mucosal microcirculation ${ }^{41}$.

The anti- ulcerogenic effect of the PPAR- $\gamma$ agonists could be also attributed to the improvement of the antioxidant status of the animals due to an increase in mucin content of the gastric mucosa ${ }^{42}$. The protective effect of the PPAR- $\gamma$ ligands against gastric injury may be explained by the increased glutathione level in gastric mucosa by two different ways. Firstly, glutathione is a cofactor in some steps of PGs synthesis, so it will help the conversion of $\mathrm{PGG}_{2}$ to $\mathrm{PGH}_{2}$ and the subsequent conversion to $\mathrm{PGE}_{2}{ }^{43}$, Secondly, through glutathione depletion, gastric damage is induced ${ }^{44}$. Prostaglandin synthetase is incapable of synthesizing $\mathrm{PGE}_{2}$ after depletion of glutathione from the medium ${ }^{45}$. PGs have an established role in the protection of gastric mucosa against different types of gastric lesions. Of particular interest is the fact that the antisecretory PGs can protect the mucosa. Moreover, the non-anti-secretory PGs, such as $\mathrm{PGF}_{2}$ are also protective $^{46}$.

It has been reported that PPAR- $\gamma$ agonists inhibit production of pro-inflammatory cytokines such as TNF- $\alpha$, IL-1 $\beta$, and IL-6. Jiang et al. 1998 demonstrated that activation of PPAR- $\gamma$ inhibited inflammatory cytokine production by stimulated monocytes/macrophages ${ }^{47}$. Konturek et al. 2010 demonstrated that PPAR- $\gamma$ agonists accelerate the healing of pre-existing acetic acid gastric ulcers in rats due to the hyperemia at ulcer margins and the anti-inflammatory action including suppression of IL- $1 \beta$, TNF- $\alpha$, COX-2 and iNOS and by an over expression of heat shock protein 70 (HSP 70) ${ }^{48}$.

This is supported by the results of present work that have shown a highly significant increase in the mean value of eNOS enzyme gene expression, a highly significant increase in the mean value of glutathione reductase enzyme gene expression and a highly significant decrease in the mean value of COX-2 enzyme activity in $\omega-3$ PUFA subgroup (Bii) compared to control subgroup (Bi).

\section{SUMMARY AND CONCLUSION}

In conclusion, the present study revealed a gastroprotective effect of chronic administration of $\omega-3$ PUFA - in the form of fish oil rich in both EPA and DHA- on stress-induced gastric ulceration.

\section{REFERENCES}

1. F.A.O. (2010). Fats and fatty acids in human nutrition.Report of an expert consultation. FAO food and nutrition paper Series 91:9-10

2. Simopoulos A.P. (1999). Essential fatty acids in health and chronic disease. Am J Clin Nutr. 70(3 Suppl): 560S-9.

3. Simopoulos A.P. (2002). Omega-3 fatty acids in inflammation and autoimmune disease, J Amr Coll Nutrit. 21(6):495-505.

4. European Food Safety Authority (EFSA) (2005). Opinion of the Scientific Panel on Dietetic Products, Nutrition and Allergies on a request from the Commission related to nutrition claims concerning omega-3 fatty acids, monounsaturated fat, polyunsaturated fat and unsaturated fat. The EFSA Journal. 253:1-29.

5. Mutlu G.M., Mutlu E.A. and Factor P. (2001). GI complications in patients receiving mechanical ventilation. Chest. 119:1222-41.

6. Martindale R.G. (2005) Contemporary strategies for the prevention of stressrelated mucosal bleeding. Am J Health Syst Pharm 62 (10 Suppl 2):S11-7.

7. Laine L., Takeuchi K. and Tarnawski A. (2008). Gastric mucosal defense and 
cytoprotection: benchto bedside.

Gastroenterology 135:41-60.

8. Appleyard C.B., McCafferty D.M., Tigley A.W., Swain M.G. and Wallace J.L. (1996). Tumor necrosis factor mediation of NSAID-induced gastric damage: role of leukocyte adherence. Am J Physiol 270:G42-8.

9. Murison R. and Overmier J.B. (1993). Some psychosomatic causal factors of restraint-in-water stress ulcers. Physiol. Behav. 53:577-81.

10. Shu G., Qian G., Qing J., Wei H., Xue G. and Ji-Min C. (2012). Gastric mucosal damage in water immersion stress: Mechanism and prevention with GHRP-6. World J Gastroenterol. 18(24):3145-55.

11. Hunter B., McDonald G.S. and Gibney M.J. (1992). The effects of acute and chronic administration of $n-6$ and n-3 polyunsaturated fatty acids on ethanolinduced gastric haemorrhage in rats. Br. J. Nutr. 67(3):501-7.

12. Shay H., Komarov S.A., Fels S.S., Meranze D., Gruenstein M. and Siplet H. (1945). A simple method for the uniform production of gastric ulceration in the rat. Gastroenterology, 4:43-61.

13. Hayase M. and Takeuchi K. (1986). Gastric acid secretion and lesion formation in rats under water immersion stress. Dig. Dis. Sci. 31: 166-71.

14. Suzuki Y., Hayashi M., Ito M., and Yamagami I. (1976). Anti ulcer effects of 4' (2 carboxyethyl) phenyl trans 4 aminomethyl cyclo-hexanecarboxylate hydrochloride (cetraxate) on various experimental gastric ulcers in rats. Japanese Journal of Pharmacology. 26(4):471-80.

15. Takagi, K., Okabe S. and R. Saziki. (1969). A new method for the production of chronic gastric ulcer in rats and the effect of several drugs on its healing. Jpn. J. Pharmacol. 19: 418-26.

16. Rajkapoor B., Anandan R. and Jayakar B. (2002). Antiulcer effect of Nigella sativa Linn. against gastric ulcer in rats. Curr. Sci. 82:177-9.

17. ${ }^{17}$ Kulmacz R.J., and Land W.E.M. (1998). Requirements for hydroperoxide by the cyclooxygenase and peroxidase activities of prostaglandin $\mathrm{H}$ synthase.Prostaglandins 25:531-540.

18. ${ }^{18}$ Faust T.W., Redfern J.S., Podolsky I., Lee E., Grundy S.M. and Feltman M. (1990). Effects of aspirin on gastric mucosal prostaglandin $\mathrm{E}$, and $\mathrm{F}$, content and on gastric mucosal injury in humans receiving fish oil or olive oil. Gastroenterology 98:586-91.

19. ${ }^{19}$ Riber C., Wojdemann M., Bisgaard T., Ingels H., Rehfeld J.F. and Olsen O. (1999). Fish oil reduces gastric acid secretion. Scand J Gastroenterol. 34:8458.

20. ${ }^{20}$ Salaj K., Mohammed A., Sunil S.D. and Satya V.P. (2008). Antiulcer activity of cod liver oil in rats. Indian $\mathrm{J}$ Pharmacol. 40(5):209-14.

21. ${ }^{21}$ Al-Harbi M.M., Islam M.W., AlShabanah O.A. and Al-Gharably N.M. (1995). Effect of acute administration of fish oil (omega-3 marine triglyceride) on gastric ulceration and secretion induced by various ulcerogenic and necrotizing agents in rats. Food Chem Toxicol. 33:553-8.

22. Takada H., Takahashi M., Takada H., Kuwayama H. and Souma R. (2004). Omega. 3 polyunsaturated fatty acid and ulcer healing. Dokkyo J Med Sci. 31:17223.

23. Li P., Lee K.Y., Chang T.M. and Chey W.Y. (1990). Hormonal mechanism of sodium oleate-stimulated pancreatic secretion in rats. Am J Physiol. 259: G960-5.

24. Shiratori K., JO Y.H., Lee K.Y., Chang TM. and Chey W.Y. (1989). Effect of pancreatic juice and trypsin on oleic acidstimulated pancreatic secretion and plasma secretin in dogs. Gastroenterology. 96:1330-6.

25. Olsen O., Ainsworth M., Schaffalitzky De Muckadell O.B. and Cantor P. (1989). Effects of oleic acid and oleyl alcohol on cholecystokinin and secretin in plasma and pancreatico-biliary secretion. Scand J Gastroenterol. 24: 529-532.

26. Konturek J.W., Stoll R., GutwinskaKonturek M., Konturek S.J. and Domschke W. (1993). Cholecystokinin in 
the regulation of gastric acid and endocrine pancreatic secretion in humans. Scand J Gastroenterol. 28: 401-7.

27. Soll A.H., Amieian D.A., Park J., Elashoff J.D. and Yamada T. (1985). Cholecystokinin potently releases somatostatin from canine fundic mucosal cells in short-term culture. Am J Physiol; 248:G569-73.

28. Schubert M.L., Bitar K.N. and Makhlouf G.M. (1982). Regulation of gastrin and somatostatin secretion by cholinergic and non-cholinergic intramural neurons. Am J Physiol. 243:G442-7.

29. Gonzalez M.V., Yago M.D., Mañas M., Calpeña R., Díaz R., Martínez-Victoria E., and Mataix J. (1998). Role of the quality of dietary fat on the postprandial levels of secretin, cholecystokinin, and pancreatic polypeptide in humans. Ars Pharmaceutica. 39(3-4):165-73.

30. Phull P.S., Green C.J. and Jacyna M.R. (1995). A radical view of the stomach: the role of oxygen-derived free radicals and anti-oxidants in gastroduodenal disease. Eur J Gastroenterol Hepatol. 7(3):265-74.

31. Bhattacharya A., Ghosal S. and Bhattacharya S.K. (1995). Effect of fish oil on offensive and defensive factors in gastric ulceration in rats. Food Chem Toxicol. 33:553-8.

32. Ulak G., Ciçek R., Sermet A., Guzel C., Ulak M. and Denli O. (1995). Protective effect of fish oil against stress-induced gastric injury in rats. Arzneimittelforschung. 45:1174-5.

33. Divakar V., Sylvia S., Sarath B.K. and Devika T. (2012). Evaluation of gastro protective activity of Fish Oil (Omega- 3 Fatty Acids) against experimentally induced acute gastric ulceration in Rats. Int. J Med Health Sci. 1:2.

34. Ozgocmen S., Atalay Catal S., Ardicoglu O. and Kamanli A. (2000). Effect of omega-3 fatty acids in the management of fibromyalgia syndrome, Int. J. Clin. Pharm. Ther. 38:362-3.

35. James M.J., Gibson R.A. and Cleland L.G. (2000). Dietary polyunsaturated fatty acids and inflammatory mediator production.

\section{The American Journal of Clinical} Nutrition. 71(1):343S-8.

36. Su K.P., Shen W.W and Huang S.Y. (2000) Are omega3 fatty acids beneficial in depression but not mania? Arch Gen Psychiatry. 57:716-7.

37. Das U.N. (2006). Essential fatty acids: biochemistry, physiology and pathology. Biotechnol J. 1:420-39.

38. Feige J.N., Gelman L., Michalik L., Desvergne B. and Wahli W. (2006). From molecular action to physiological outputs: peroxisome proliferator-activated receptors are nuclear receptors at the crossroads of key cellular functions. Progress in Lipid Research. 45(2):120-59.

39. Shimada T., Koitabashi A., Kuniyoshi T., Hashimoto T., Yoshiura K., Yoneda M., Hiraishi H. and Terano A. (2003). Upregulation of TFF expression by PPARgamma ligands in gastric epithelial cells. Alimentary pharmacology \&therapeutics. 18 Suppl 1:119-25.

40. Konturek P.C., Brzozowski T., Burnat G., Szlachcic A., Koziel J., Kwiecien S., Konturek S.J. and Harsch I.A. (2010). Gastric ulcer healing and stress-lesion preventive properties of pioglitazone are attenuated in diabetic rats. Journal of physiology and Pharmacology. 61(4):42936.

41. Kawano S. and Tsuji S. (2000). Role of mucosal blood flow: a conceptional review in gastric mucosal injury and protection. $\mathbf{J}$ Gastroenterol Hepatol. 15(Suppl):D1-D6.

42. Tarek A. and Samar S.E. (2006). Effect of peroxisome proliferator- activated receptor-gamma (PPAR- $\gamma$ ) ligands on gastric mucosal injury induced by ischemia/reperfusion in rats. Bull. Alex. Fac. Med. 42(1).

43. ${ }^{43}$ Chan J.A., Nagaswa M., Takeguchi C. and Sih C.J. (1975) on agents favoring prostaglandin $\mathrm{E}$ formation during biosynthesis. Biochemistry. 14:2987-91.

44. Jimmy Y.C., Chow L.M., Min Z. and Chi H.C.H. (1997). The potentiating actions of cigarette smoking on ethanol-induced gastric mucosal damage in rats. Gastroenterology. 113:1188-97. 
45. Wallach D.P. and Daniele E.G. (1971). Properties of novel preparation of prostaglandin synthetase from seminal vesicles. Biochem. Biophys. Acta. 231:445-57.

46. Alarcon C., Lopez A. and Motilva V. (1993). Gastro-protection and prostaglandin E2 generation in rats by flavonoids of Dittrichia viscosa. Planta Medica. 59: 497-501.

47. Jiang C., Ting A.T. and Seed B. (1998). PPAR-gamma agonists inhibit production of monocyte inflammatory cytokines. Nature. 391:82-6.

48. Konturek P.C., Brzozowski T., Burnat G., Szlachcic A., Koziel J., Kwiecien S., Konturek S.J. and Harsch I.A. (2010). Gastric ulcer healing and stress-lesion preventive properties of pioglitazone are attenuated in diabetic rats. Journal of physiology and Pharmacology. 61(4):42936. 